$\begin{array}{ll}\text { Research Square } & \begin{array}{l}\text { Preprints are preliminary reports that have not undergone peer review. } \\ \text { They should not be considered conclusive, used to inform clinical practice, } \\ \text { or referenced by the media as validated information. }\end{array}\end{array}$

\title{
Vitamin D recommendations in nutritional guidelines: A systematic quality evaluation using AGREE-2 and analysis of potential predictors
}

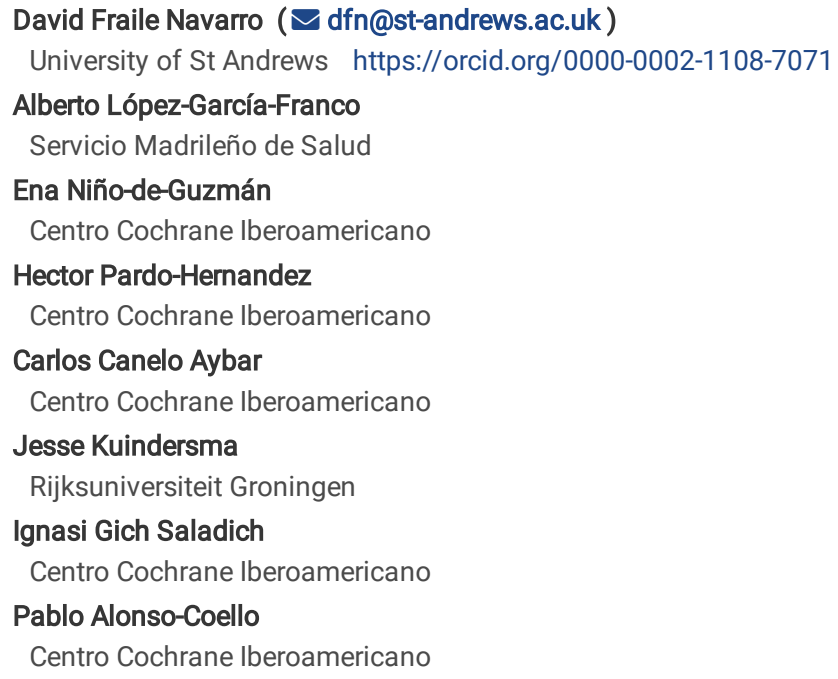




\section{Abstract}

Background Vitamin D has been widely promoted for bone health through supplementation and fortification of the general population. However, there is growing evidence that does not support these strategies. Our aim is to review the quality and recommendations on vitamin D nutritional and clinical practice guidelines and explore predictive factors for their direction and strength. Methods We searched Medline, TRIP, G-I-N and guidelines.gov databases for guidelines from January 2010 to January 2018. We performed a descriptive analysis, a quality appraisal using AGREE II scores (Appraisal of Guidelines Research and Evaluation) and a bivariate analysis evaluating the association between direction and strength of recommendations, three AGREE II domains' scores (Rigor of development, Applicability and Editorial Independence) and pre-specified characteristics. Results We included 24 guidelines in our review. Nine recommended supplementations, eight suggested its use, and seven did not recommended it. AGREE II mean scores were $40.1 \%$ for "Rigor of development", $34.5 \%$ for "Applicability, and 39.6\% for "Editorial independence". Guidelines with higher scores in these domains were less likely to recommend or suggest vitamin D supplementation ( $64 \%$ recommending against vs $29 \%$ suggesting for, and $27 \%$ recommending for; $p=0.002,52 \%$ vs $26 \%$ and $25 \%$; $p=0.003,61 \%$ vs $35 \%$ and $24 \% ; p=0.001$, respectively). Guidelines with potential conflicts of interest were more likely to recommend or suggest vitamin $D$ supplementation (likelihood ratio: $\mathrm{p}=0.018$ ). Conclusions Policy makers, clinicians and patients should be aware that lower quality guidelines, and those reporting conflicts of interest are more likely to promote vitamin D supplementation. Guideline organizations should improve the quality of their recommendations' development, and the management of conflicts of interest. Users and editors should be aware of these findings when using and appraising guidelines.

\section{Background}

Vitamin D plays a vital role in several physiological processes(1-4). The best understood of these functions is calcium regulation, counter regulating parathyroid hormone secretion to maintain calcium serum levels(5) and fixing calcium absorption. It is predominantly synthesized via direct sunlight (ultraviolet B radiation) exposure(6), as it is limited to only a few natural sources(7) in human diet. Severe deficiency leads to rickets in children and osteomalacia in adults; its deficit has been associated with low bone mineral density(8), and increased risk of fractures(9).

Public health concerns about suboptimal vitamin D intake have led to the development of dietary and supplementation recommendations(10) in nutritional guidelines. However, the link between vitamin D intake and fracture risk is controversial(11). These recommendations were initially addressed to populations at risk of low sun exposure, particularly in northern latitudes(12). Early systematic reviews(13-15) showed a decrease in fractures among older institutionalized women, while more recent ones have demonstrated the absence of beneficial effect(16-22). Of note is the absence of randomized clinical trials in the general population to evaluate outcomes such as fractures, with only surrogate outcomes (e.g. bone mineral density and 25-hydroxycholecalciferol (25-OH-D)(23) being available. Vitamin D supplementation has not shown any effect in preventing cardiovascular disease or cancer(24-26), and high doses paradoxically, have been associated with an increase in falls in the elderly(27).

Another subject of debate is what constitutes vitamin D deficiency. While some studies declared epidemic proportions of deficiency(28), others have not confirmed these claims(10). Typically assessed with 25-OH-D serum levels, the threshold to maintain adequate bone health is also disputed(10).

Our aim is to review and analyze Vitamin D recommendations present in nutritional and clinical practice guidelines (CPGs) as well as potential related factors for these recommendations.

\section{Methods}

We searched Medline via PubMed, Guidelines.gov, the Guidelines International Network (G-I-N), and Trip Database. We conducted our search for CPGs published between January 2010 and January 2018. The full search strategy can be found in the Supplementary File 1.

\section{Eligibility criteria}

We included guideline publications, following the definition of the Institute of Medicine(29). We included guidelines that formulated recommendations for vitamin D intake, and/or screening for the general, healthy population. We excluded guidelines addressed to pediatric population (to prevent rickets), guidelines on specific conditions (e.g. chronic corticoid users), guidelines addressed to osteoporotic patients exclusively, or for secondary prevention of osteoporotic fractures.

\section{Data extraction}

We collected: year of publication, institution, region, target population, proposed vitamin D levels, calcium advice (if given), sun exposure advice, screening advice, fortification advice, suggested methods for vitamin D obtention, and supplementation recommendations. Three reviewers (DF, EN and JK) conducted screening, data extraction, and quality assessment. We resolved disagreements through discussion or with the help of another reviewer (PA). We classified the recommendations following the distinction that the Grading of Recommendations Assessment, Development and Evaluation (GRADE) provides(30) in three categories: "Recommends in favor", for unequivocal, strong recommendations; "Suggests in favor", for weak or conditional recommendations; and "Does not recommend", for guidelines which did not provided advice in favor or recommended against supplementation.

We also collected information concerning authors' potential conflicts of interest (COIs) and how these were managed. We focused on evaluating individual COls reporting and the potential Institutional COls in accordance with methodology implemented in previous evaluations(31,32). We recorded if organizations 
addressed affiliation, financial and intellectual COls in their report. We also collected the type of organization that formulated the recommendations and, if available, the institution's potential financial or advocatory COIs(32). Two reviewers (DF and CC) collected this data independently. In case of disagreement, we solved it by discussion and the help of a third reviewer (PA).

\section{Quality appraisal}

We used the AGREE II (Appraisal of Guidelines Research and Evaluation version 2)(33) instrument. This tool evaluates the methodological rigor and transparency with which a guideline is developed. We restricted our assessment to the Rigor of Development, Applicability, and Editorial Independence domains (Supplementary Box 1). AGREE II does not provide a "general" score of the guideline quality, hence, given the scope of our review, we focused on three specific subdomains for our quality appraisal. "Rigor of development" provides a rationale of the methodological strength of the guideline. "Applicability" addresses issues regarding the advice given on its recommendations' implementation. Finally, besides our specific analysis of conflicts of interest, "Editorial independence" provided us additional information on this matter. After calibration, two researchers evaluated publications independently. We calculated the percentage of the maximum possible score for each domain, and its standardized range (from $0 \%$ to $100 \%$ ).

\section{Data analysis}

We performed a descriptive analysis for each included guideline. We assessed the reproducibility of quantitative measurements made by different observers by calculating the intra-class correlation coefficients (ICC), and the associated 95\% confidence intervals (CI) for each AGREE II domain. We conducted a bivariate analysis to evaluate the potential association between recommendations and AGREE II scores with the following factors: region, type of organization, target population, suggested method to obtain Vitamin D, advice on sun exposure, advice on fortifying strategies, and conflicts of interest. We included in our logistic regression model the results that remained significant in the bivariate analysis.

\section{Results}

The initial search yielded 491 references. Forty-five guidelines were selected for full text review and 24 guidelines were finally included in our analysis (Figure 1). Nine (38\%) guidelines were from the USA or Canada, seven (29\%) from Europe, four (16\%) from Asia, two (8\%) from Australia and New Zealand, and two (8\%) from international organizations. By type of society: fourteen (56\%) guidelines were developed by scientific societies, two ( $8 \%$ ) by international governmental organizations, and nine $(36 \%)$ by national governmental organizations.

Thirteen (54\%) guidelines targeted general adult population, ten (42\%) addressed older populations ( $\geq 50$ years old), and one (4\%) targeted pregnant women. Regarding vitamin D screening, eight (33\%) guidelines recommended vitamin D screening to individuals with risk factors (e.g. dark skin or low sun exposure) (Table 1 and Table 2).

Nine (38\%) guidelines recommended in favor of some form of supplementation of vitamin D at some stage in life, seven (29\%) suggested it, and eight (33\%) did not recommend or recommended against supplementation. By population, eleven (46\%) guidelines recommended or suggested supplementation for the general population, eight (33\%) recommended supplementation for pediatric population, six (25\%) recommended or suggested supplementation in pregnant women, and twenty-three (96\%) recommended it for the elderly and institutionalized patients. The daily intake recommended varied from 400 International Units (IU) to 4000 IU (SD 621.33), the mode being 800 IU. (Table 1 and Table 2 and Supplementary Table 1).

With respect to vitamin D obtention, six guidelines (25\%) highlighted the importance of sun exposure to achieve enough vitamin D levels. Twenty guidelines (83\%) recommended supplementation as the favored method to obtain adequate vitamin D levels, two (8\%) recommended sun exposure, and two guidelines (8\%) did not provide a specific method. Five guidelines (21\%) recommended vitamin D fortification strategies, either mandatory or voluntary. Regarding vitamin D screening, eight (33\%) guidelines recommended vitamin D screening for individuals with risk factors.

In the subdomains of AGREE II evaluated (Figure 2 and Supplementary Table 1), the mean score was 40.1\% for Rigor of Development (range 10.4\%-90.9\%; Standard Deviation (SD): 23.5\%), 34.5\% for Applicability (range 12.5\%-77.1\%; SD: 18.1\%), and 39.6\% for Editorial Independence (range 8.3\%-80.6\%; SD: $19.8 \%)$. Six (25\%) guidelines reached a score over $50 \%$ for Rigor of Development, Applicability, and Editorial Independence domains. The ICC was 0.954 (Cl95\% 0.887-0.980) for Rigor of Development, 0.91 (Cl95\% 0.815-0.96) for Applicability and 0.854 (CI95\% 0.682-0.938) for Editorial Independence. See Supplementary File 2 for the detailed score of the guidelines included.

Regarding conflicts of interest (COI) reporting, 19 out of 24 (79\%) guidelines reported an explicit process to manage them, in two (8\%) the process was unclear and four (17\%) did not report any related information. Twenty three out of 24 (96\%) reported affiliations, whereas 2 ( $8 \%$ ) did not. In 19 out of 24 (79\%) reported financial ties, two (8\%) did not reported them clearly and four (17\%) did not report them at all. Intellectual COI were reported in seven out of 24 guidelines (29\%), with 18 (75\%) not providing any information. Regarding institutional financial ties five guidelines (21\%) reported them, thirteen (54\%) did not provide any information, and seven (29\%) were unclear. When examining if the institution potentially played an advocatory role favoring intervention, we detected this in five cases (21\%), eight (33\%) being unclear. Overall, we considered 15 out of 24 guidelines (63\%) to have potential COIs (Table 3).

The guidelines that do not recommend vitamin D supplementation (compared with those that suggested or recommended it) scored significantly higher in the Rigor of Development domain (64\% recommending against vs $29 \%$ suggesting, and $27 \%$ recommending for; $p=0.002$ ), Applicability ( $52 \%$ vs $26 \%$ and $25 \%$; 
$\mathrm{p}=0.003)$ and Editorial Independence $(61 \%$ vs $35 \%$ and $24 \% ; p=0.001)$ respectively. A post-hoc analysis showed no significant differences between the "suggest" and "recommend" categories.

Guidelines that provided recommendations in favor of vitamin D supplementation were associated with conflicts of interest, either detected or declared (likelihood ratio $\mathrm{p}=0.018$ ). In the logistic regression model, Rigor of Development and Applicability were independent predictors of recommending vitamin $\mathrm{D}$ supplementation; the higher the score, the less likely supplementation was recommended Odds Ratio (OR) 1.11; Cl95\% 1.02-1.19 and OR 1.15; CI95\% 1.03-1.28 respectively. With respect to vitamin D screening, we found a significant association between recommending screening and lower AGREE II scores for Rigor of Development, Applicability and Editorial Independence ( $50 \%$ vs $24 \% p=0.002 ; 41 \%$ vs $24 \% p=0.007 ; 46 \%$ vs $31 \% p=0.05$ ).

Finally, guidelines that declared no conflicts of interest, and guidelines in which no conflicts of interest were detected scored significantly higher in "Rigor of Development", "Applicability" and "Editorial independence" domains, compared to those guidelines that did not, or for which conflicts of interest were detected ( $54 \%$ vs $32 \% p=0.033 ; 48 \%$ vs $27 \% p=0.022$, and; $51 \%$ vs $33 \% p=0.024$ ). We did not find any other associations with respect to the rest of predefined variables.

\section{Discussion}

Our systematic assessment of vitamin D recommendations shows that despite the lack of conclusive evidence, most organizations recommend vitamin $D$ supplementation for the general population. With a few exceptions, the guidelines included were generally of low quality. More importantly, those with lower scores or with conflicts of interest were more likely to recommend wider supplementation.

In general, our results resonate with previous AGREE II evaluations where low scores were reported for the majority of guideline topics(34-39). This finding could suggest that guideline development is not directly related to the quality of the underlying evidence. While the guidelines identified recommended population supplementation, the Institute of Medicine (IOM) landmark systematic report, recognized the low quality of the available evidence about vitamin D supplementation, favoring supplementation only in specific situations with minimum sun exposure(10). Paradoxically, this report is cited in most of the guidelines evaluated, to support strong recommendations towards supplementation. Furthermore, the IOM report acknowledged that the thresholds proposed by some organizations amplify the sense of an "epidemic of deficiency that does not correlate with epidemiological data"(10). By contrast, renowned organizations evaluated in our study, such as the National Osteoporosis Foundation, do not rate the quality of the evidence, nor the strength of the recommendations for populations with very different baseline risk (institutionalized vs community), and extrapolate effectiveness evidence from women to men. GRADE contemplates five exceptional situations in which a strong recommendation may be warranted in the face of low-quality evidence. For example, when it suggests benefit in a life-threatening situation(40). None of these apply for the situation we described.

Our results are also in agreement with previously reported ties between industry, advocacy and academia in this field( $(41,42)$. We provide much needed empirical observational evidence illustrating that conflicts of interest are associated with more interventionist recommendations. According to one systematic review about conflicts of interest in practice guidelines, the authors were not able to identify studies informing about the effect of COI on recommendations(43). Although our assessment is an indirect measure, the observed signal is significant, and is consistent with the expected direction(41,42).

Although we did not focus on pediatric guidelines, we detected population-level vitamin D supplementation recommendations for children, even when the incidence of rickets continues to be rare in the developed world, despite some reports of an increase $(44,45)$. In developing countries, given that most of them are situated relatively close to the equator, which grants enough UVB sun exposure all year-round, putting emphasis on vitamin D rather than on correct nutrition seems a futile approach to child health care. Similarly, the World Health Organization, in their publication on vitamin D supplementation in pregnant women, acknowledges that adequate nutrition in pregnant women is best achieved through a healthy balanced diet(46). Supplementation or fortification may be justified in northern latitudes, especially in higher risk sub-populations such as dark-skinned individuals, people who do not spend enough time outdoors, and women who fully cover themselves for religious or cultural reasons(10).

Some additional concerns in the recommendations we evaluated were mostly based on the use of surrogate markers, such as bone mineral density or serum levels of 25-OH-D for defining vitamin D deficiency. This is problematic given that the correlation between intake, desirable serum levels and preventive effects is unclear(10). Also, despite the fact that there might be a potential beneficial effect of supplementation with calcium and vitamin $D$ in specific subgroups, such as institutionalized elderly women(13), extrapolating supplementation to the general population is not necessarily straight forward. Especially when the certainty of evidence is low. Finally, there is also the potential risk for medicalization and the economic implications of testing and clinical appointments(47).

We encourage end users of recommendations to remain cautious when using recommendations in this field, especially those developed with unclear methods, those with potential conflicts of interest, and those targeting the general population. Recommendation developers should adhere to rigorous methods and use actionable, standardized language. We urge scientific societies and governmental organizations to adopt a cautionary approach when recommending preventive or screening interventions addressed to the general population. Lastly, organizations and journals should address conflicts of interest more transparently.

\section{Limitations}

We restricted our literature search to guideline repositories and Medline. However, most of the relevant guidelines are likely to have been captured, given how representative of published guidelines MEDLINE and the searched databases are. We did not perform a full AGREE II evaluation, but the direction and scoring of the domains analyzed were However, this study had several strengths. To our knowledge, is the first systematic assessment of published guidelines that 
inform about the effect of $\mathrm{COI}$ on recommendations. We performed our analysis using rigorous and transparent methods. The evaluation of the relationship of several pre-specified factors with more interventionist recommendations provides relevant information for developers, and users, including policy makers.

\section{Conclusions}

Vitamin D has been one of the most widely studied topics in medicine. Nonetheless, high quality, conclusive evidence about a net beneficial effect with its supplementation is lacking. The scientific community should probably start recognizing that vitamin D is not the "magic bullet" it appeared to be, and that its implication in physiological processes is likely to be tangential, rather than causal. Future research should probably be directed to improving lifestyles(48) rather than medicalizing healthy populations.

\section{Abbreviations}

AGREE II: Appraisal of Guidelines Research and Evaluation / Appraisal of Guidelines Research and Evaluation version 2

25-OH-D: 25-hydroxycholecalciferol

CPGs: Clinical Practice Guidelines

G-I-N: Guidelines International Network

GRADE: Grading of Recommendations Assessment, Development and Evaluation

COI: Conflicts of interest

ICC: Intra-class correlation coefficient

Cl: Confidence interval

IU: International Units

SD: Standard deviation

OR: Odds Ratio

IOM: Institute of Medicine

\section{Declarations}

\section{Ethics approval and consent to participate}

Not applicable.

\section{Consent for publication}

Not applicable.

Availability and data material

All data generated or analyzed during this study are included in this published article (and its supplementary information files).

Competing interests:

The authors declare that they have no competing interests.

\section{Funding:}

The project was not funded. Funding for English language editing and publication fees was obtained via an award from the foundation for Biomedical Research and innovation in Primary Care (Fundación para la Investigación e Innovación Biomédica en Atención Primaria). The project had no other sources of funding.

\section{Authors' contributions}

DF contributed to design, data extraction, data analysis and wrote this manuscript. AL collaborated in design, helped with data analysis and collaborated in manuscript redaction. EN and EP collaborated in data extraction and manuscript redaction. CC and JK collaborated in data extraction. IG collaborated in data analysis and statistical advice. PA collaborated in design, data analysis and manuscript redaction.

\section{Acknowledgments}


We want to acknowledge the "Fundación para la Investigación e Innovación Biomédica en Atención Primaria" for a grant for covering publication fees and language editing. Pablo Alonso-Coello is supported by a Miguel Servet investigator contract from the Instituto de Salud Carlos III (CPII15/0034). David Fraile Navarro is supported by an NHS Education for Scotland fellowship program.

\section{References}

1. Rosen CJ, Adams JS, Bikle DD, Black DM, Demay MB, Manson JE, et al. The Nonskeletal Effects of Vitamin D: An Endocrine Society Scientific Statement. Endocr Rev [Internet]. 2012 Jun 17;33(3):456-92. Available from: http://www.ncbi.nlm.nih.gov/pmc/articles/PMC3365859/

2. Theodoratou E, Tzoulaki I, Zgaga L, loannidis JPA. Vitamin D and multiple health outcomes: umbrella review of systematic reviews and meta-analyses of observational studies and randomised trials. BMJ [Internet]. 2014 Jan 1 [cited 2016 Jul 8];348(apr01_2):g2035. Available from:

http://www.bmj.com/content/348/bmj.g2035

3. Martineau AR, Jolliffe DA, Hooper RL, Greenberg L, Aloia JF, Bergman P, et al. Vitamin D supplementation to prevent acute respiratory tract infections: systematic review and meta-analysis of individual participant data. BMJ [Internet]. 2017;356. Available from:

http://www.bmj.com/content/356/bmj.i6583

4. Castro M, King TS, Kunselman SJ, Cabana MD, Denlinger L, Holguin F, et al. Effect of Vitamin $D_{3}$ on Asthma Treatment Failures in Adults With Symptomatic Asthma and Lower Vitamin D Levels. JAMA [Internet]. 2014 May 28 [cited 2017 Apr 6];311(20):2083. Available from: http://jama.jamanetwork.com/article.aspx?doi=10.1001/jama.2014.5052

5. Suda T, Shinki T, Kurokawa K. The mechanisms of regulation of vitamin D metabolism in the kidney. Curr Opin Nephrol Hypertens [Internet]. 1994 Jan [cited 2018 Jan 15];3(1):59-64. Available from: http://www.ncbi.nlm.nih.gov/pubmed/7850413

6. Webb AR, Engelsen O. Calculated Ultraviolet Exposure Levels for a Healthy Vitamin D Status. Photochem Photobiol [Internet]. 2006 [cited 2017 Jun 2];82(6):1697. Available from: http://doi.wiley.com/10.1562/2006-09-01-RA-670

7. Bischoff-Ferrari HA, Keller U, Burckhardt P, Lötscher KQ, Gerber B, l'Allemand D, et al. Recommandations de la Commission fédérale de l'alimentation concernant l'apport de vitamine D. In: Forum Med Suisse. 2012. p. 775-8.

8. Wacker M, Holick MF. Vitamin D-Effects on Skeletal and Extraskeletal Health and the Need for Supplementation. Nutrients [Internet]. 2013 Jan 10;5(1):111-48. Available from: http://www.ncbi.nlm.nih.gov/pmc/articles/PMC3571641/

9. Cummings SR, Browner WS, Bauer D, Stone K, Ensrud K, Jamal S, et al. Endogenous hormones and the risk of hip and vertebral fractures among older women. N Engl J Med. 1998;339(11):733-8.

10. Ross AC, Taylor CL, Yaktine AL, Del Valle HB. Dietary reference intakes for calcium and vitamin D. National Academies Press; 2011.

11. Bolland MJ, Leung W, Tai V, Bastin S, Gamble GD, Grey A, et al. Calcium intake and risk of fracture: systematic review. 2015;

12. Webb AR, Kline L, Holick MF. Influence of Season and Latitude on the Cutaneous Synthesis of Vitamin D3: Exposure to Winter Sunlight in Boston and Edmonton Will Not Promote Vitamin D3 Synthesis in Human Skin*. J Clin Endocrinol Metab. 1988;67(2):373-8.

13. Chapuy MC, Arlot ME, Duboeuf F, Brun J, Crouzet B, Arnaud S, et al. Vitamin D3 and calcium to prevent hip fractures in elderly women. N Engl J Med. 1992;327(23):1637-42.

14. Tang BMP, Eslick GD, Nowson C, Smith C, Bensoussan A. Use of calcium or calcium in combination with vitamin D supplementation to prevent fractures and bone loss in people aged 50 years and older: a meta-analysis. Lancet. 2007;370(9588):657-66.

15. Bischoff-Ferrari HA, Dawson-Hughes B, Staehelin HB, Orav JE, Stuck AE, Theiler R, et al. Fall prevention with supplemental and active forms of vitamin D: a meta-analysis of randomised controlled trials. Bmj. 2009;339:b3692.

16. Chung M, Balk EM, Brendel M, Ip S, Lau J, Lee J, et al. Vitamin D and calcium: a systematic review of health outcomes. Evid Rep Technol Assess (Full Rep). 2009;183(183):1-420.

17. Bolland MJ, Grey A, Gamble GD, Reid IR. The effect of vitamin D supplementation on skeletal, vascular, or cancer outcomes: a trial sequential metaanalysis. lancet Diabetes Endocrinol. 2014;2(4):307-20.

18. Chung M, Lee J, Terasawa T, Lau J, Trikalinos TA. Vitamin D with or without calcium supplementation for prevention of cancer and fractures: an updated meta-analysis for the US Preventive Services Task Force. Ann Intern Med. 2011;155(12):827-38.

19. Roth DE, Leung M, Mesfin E, Qamar H, Watterworth J, Papp E. Vitamin D supplementation during pregnancy: state of the evidence from a systematic review of randomised trials. bmj. 2017;359:j5237.

20. Zhao J-G, Zeng X-T, Wang J, Liu L. Association Between Calcium or Vitamin D Supplementation and Fracture Incidence in Community-Dwelling Older Adults. JAMA [Internet]. 2017 Dec 26 [cited 2017 Dec 28];318(24):2466. Available from: http://jama.jamanetwork.com/article.aspx? doi $=10.1001 /$ jama.2017.19344

21. Zhao J-G, Zeng X-T, Wang J, Liu L. Association Between Calcium or Vitamin D Supplementation and Fracture Incidence in Community-Dwelling Older Adults. JAMA [Internet]. 2017 Dec 26 [cited 2018 Jan 15];318(24):2466. Available from: http://www.ncbi.nlm.nih.gov/pubmed/29279934

22. Bolland MJ, Grey A, Avenell A. Effects of vitamin D supplementation on musculoskeletal health: a systematic review, meta-analysis, and trial sequential analysis. Lancet Diabetes Endocrinol. 2018;6(11):847-58.

23. Bischoff-Ferrari HA, Dietrich T, Orav EJ, Dawson-Hughes B. Positive association between 25-hydroxy vitamin D levels and bone mineral density: a population-based study of younger and older adults. Am J Med. 2004;116(9):634-9.

24. Scragg R, AW S, Waayer D, al et. Effect of monthly high-dose vitamin d supplementation on cardiovascular disease in the vitamin d assessment study: A randomized clinical trial. JAMA Cardiol [Internet]. 2017 Apr 5; Available from: http://dx.doi.org/10.1001/jamacardio.2017.0175 
25. Manson JE, Bassuk SS, Buring JE, GD G, IR R. Vitamin D, Calcium, and Cancer. JAMA [Internet]. 2017 Mar 28 [cited 2017 Apr 6];317(12):1217. Available from: http://jama.jamanetwork.com/article.aspx?doi=10.1001/jama.2017.2155

26. Lappe J, Watson P, Travers-Gustafson D, Recker R, Garland C, Gorham E, et al. Effect of Vitamin D and Calcium Supplementation on Cancer Incidence in Older Women. JAMA [Internet]. 2017 Mar 28 [cited 2017 Apr 6];317(12):1234. Available from: http://jama.jamanetwork.com/article.aspx? doi=10.1001/jama.2017.2115

27. Sanders KM, Stuart AL, Williamson EJ, Simpson JA, Kotowicz MA, Young D, et al. Annual high-dose oral vitamin D and falls and fractures in older women: a randomized controlled trial. Jama. 2010;303(18):1815-22.

28. Holick MF. High prevalence of vitamin D inadequacy and implications for health. Mayo Clin Proc [Internet]. 2006 Mar 1 [cited 2017 Jan 5];81(3):353-73. Available from: http://www.mayoclinicproceedings.org/article/S0025619611614651/fulltext

29. Guidelines I of M (US) C on S for DTCP, Graham R, Mancher M, Wolman DM, Greenfield S, Steinberg E. Clinical Practice Guidelines We Can Trust [Internet]. Clinical Practice Guidelines We Can Trust. National Academies Press (US); 2011 [cited 2018 Nov 21]. Available from: http://www.ncbi.nlm.nih.gov/pubmed/24983061

30. Schünemann H, Brozek J, Oxman A. GRADE handbook for grading quality of evidence and strength of recommendations. Updat Oct. 2013;

31. Erickson J, Sadeghirad B, Lytvyn L, Slavin J, Johnston BC. The scientific basis of guideline recommendations on sugar intake: A systematic review. Ann Intern Med. 2017;166(4):257-67.

32. Hakoum MB, Anouti S, Al-Gibbawi M, Abou-Jaoude EA, Hasbani DJ, Lopes LC, et al. Reporting of financial and non-financial conflicts of interest by authors of systematic reviews: a methodological survey. BMJ Open. 2016;6(8):e011997.

33. Brouwers MC, Kho ME, Browman GP, Burgers JS, Cluzeau F, Feder G, et al. AGREE II: advancing guideline development, reporting and evaluation in health care. CMAJ [Internet]. 2010 Dec 14 [cited 2017 Jan 3];182(18):E839-42. Available from: http://www.cmaj.ca/content/182/18/E839.short

34. Kung J, Miller RR, Mackowiak PA. Failure of Clinical Practice Guidelines to Meet Institute of Medicine Standards. Arch Intern Med [Internet]. 2012 Nov 26 [cited 2017 Oct 4];172(21):1628. Available from: http://archinte.jamanetwork.com/article.aspx?doi=10.1001/2013.jamainternmed.56

35. Armstrong JJ, Goldfarb AM, Instrum RS, MacDermid JC. Improvement evident but still necessary in clinical practice guideline quality: a systematic review. J Clin Epidemiol [Internet]. 2017 Jan 1 [cited 2017 Oct 4];81:13-21. Available from: http://www.ncbi.nlm.nih.gov/pubmed/27565978

36. Alonso-Coello P, Irfan A, Sola I, Gich I, Delgado-Noguera M, Rigau D, et al. The quality of clinical practice guidelines over the last two decades: a systematic review of guideline appraisal studies. BMJ Qual Saf [Internet]. 2010 Dec 1 [cited 2017 Oct 4];19(6):e58-e58. Available from: http://www.ncbi.nlm.nih.gov/pubmed/21127089

37. Bennett WL, Odelola OA, Wilson LM, Bolen S, Selvaraj S, Robinson KA, et al. Evaluation of Guideline Recommendations on Oral Medications for Type 2 Diabetes MellitusA Systematic Review. Ann Intern Med. 2012;156(1_Part_1):27-36.

38. Nuckols TK, Anderson L, Popescu I, Diamant AL, Doyle B, Di Capua P, et al. Opioid prescribing: a systematic review and critical appraisal of guidelines for chronic pain. Ann Intern Med. 2014;160(1):38-47.

39. Acuña-Izcaray A, Sánchez-Angarita E, Plaza V, Rodrigo G, de Oca MM, Gich I, et al. Quality assessment of asthma clinical practice guidelines: a systematic appraisal. Chest. 2013;144(2):390-7.

40. Schünemann H, Brozek J, Oxman A. GRADE handbook for grading quality of evidence and strength of recommendation. GRADE Work Gr. 2009;

41. Grey A, Bolland M. Web of industry, advocacy, and academia in the management of osteoporosis. Bmj [Internet]. 2015;3170(July):h3170. Available from: http://www.bmj.com/lookup/doi/10.1136/bmj.h3170

42. Classen DC, Mermel LA, DJ A, JL H, S G, E S. Specialty Society Clinical Practice Guidelines. JAMA [Internet]. 2015 Sep 1 [cited 2017 Jul 18 ];314(9):871. Available from: http://jama.jamanetwork.com/article.aspx?doi=10.1001/jama.2015.7462

43. Norris SL, Holmer HK, Ogden LA, Burda BU. Conflict of Interest in clinical practice guideline development: a systematic review. PLoS One [Internet]. $2011 ; 6$. Available from: http://dx.doi.org/10.1371/journal.pone.0025153

44. Creo AL, Thacher TD, Pettifor JM, Strand MA, Fischer PR. Nutritional rickets around the world: an update. Paediatr Int Child Health [Internet]. 2017 Apr 3 [cited 2017 Apr 29];37(2):84-98. Available from: https://www.tandfonline.com/doi/full/10.1080/20469047.2016.1248170

45. Thacher TD, Fischer PR, Tebben PJ, Singh RJ, Cha SS, Maxson JA, et al. Increasing Incidence of Nutritional Rickets: A Population-Based Study in Olmsted County, Minnesota. Mayo Clin Proc [Internet]. 2013 Feb;88(2):176-83. Available from: http://www.ncbi.nlm.nih.gov/pmc/articles/PMC3612965/

46. WHO | Archived: Vitamin D supplementation in pregnant women. WHO [Internet]. 2016 [cited 2017 Apr 29]; Available from: http://www.who.int/nutrition/publications/micronutrients/guidelines/vit_d_supp_pregnant_women/en/\#.WQS42ExmHdE.mendeley\&title=Archived: Vitamin D supplementation in pregnant women\&description=EN Nutrition - Publications - Micronutrients - Guidelines - Guideline: Vitamin D supplementation in pregnant women

47. LeFevre ML, LeFevre NM. Vitamin D Screening and Supplementation in Community-Dwelling Adults: Common Questions and Answers. Am Fam Physician. 2018;97(4).

48. McNally S, Nunan D, Dixon A, Maruthappu M, Butler K, Gray M. Focus on physical activity can help avoid unnecessary social care. BMJ [Internet]. 2017 Oct 17 [cited 2017 Oct 19];359:j4609. Available from: http://www.ncbi.nlm.nih.gov/pubmed/29042359

\section{Tables}

Table 1: Vitamin D recommendations in guidelines 


\begin{tabular}{|c|c|c|c|c|c|c|c|c|c|}
\hline $\begin{array}{l}\text { GUIDELINE NAME, } \\
\text { INSTITUTION }\end{array}$ & REGION & YEAR & $\begin{array}{c}\text { TARGET } \\
\text { POPULATION }\end{array}$ & $\begin{array}{c}\text { VITAMIN D } \\
\text { SUPPLEMENTATION }\end{array}$ & $\begin{array}{l}\text { VITAMIN D } \\
\text { SCREENING } \\
\text { ADVICE }\end{array}$ & $\begin{array}{l}\text { CALCIUM } \\
\text { ADVICE }\end{array}$ & $\begin{array}{l}\text { FAVOURED } \\
\text { METHOD FOR } \\
\text { VTTAMIN D }\end{array}$ & $\begin{array}{l}\text { SUN } \\
\text { EXPOSITION } \\
\text { ADVICE }\end{array}$ & $\begin{array}{r}\text { FORTIF } \\
\text { ADVI } \\
\text { GIVEN } \\
\text { VITAM } \\
\end{array}$ \\
\hline 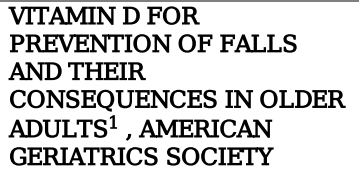 & $\begin{array}{c}\text { North } \\
\text { America }\end{array}$ & 2014 & $\begin{array}{l}\text { Population older } \\
\text { than } 65\end{array}$ & Recommends & $\begin{array}{l}\text { With risk } \\
\text { factors }\end{array}$ & No & Supplementation & No & $\mathrm{Nc}$ \\
\hline $\begin{array}{l}\text { BUILDING HEALTHY BONES } \\
\text { THROUGHOUT LIFE AN } \\
\text { EVIDENCE-INFORMED } \\
\text { STRATEGY TO PREVENT } \\
\text { OSTEOPOROSIS IN } \\
\text { AUSTRALIA }{ }^{2} \text { AUSTRALIA } \\
\text { AND NEW ZEALAND BONE } \\
\text { AND MINERAL SOCIETY \& } \\
\text { OSTEOPOROSIS } \\
\text { AUSTRALIA }\end{array}$ & Oceania & 2013 & $\begin{array}{c}\text { General } \\
\text { population }\end{array}$ & $\begin{array}{l}\text { Does not } \\
\text { recommend* }\end{array}$ & $\begin{array}{l}\text { With risk } \\
\text { factors }\end{array}$ & Yes & Sun exposure & Yes & Nc \\
\hline $\begin{array}{l}\text { OSTEOPOROSIS: } \\
\text { DIAGNOSIS, TREATMENT, } \\
\text { AND FRACTURE } \\
\text { PREVENTION }^{3}, \text { BRITISH } \\
\text { COLUMBIA MEDICAL } \\
\text { ASSOCIATION }\end{array}$ & $\begin{array}{l}\text { North } \\
\text { America }\end{array}$ & 2011 & $\begin{array}{c}\text { General } \\
\text { population }\end{array}$ & Recommends & No & No & Supplementation & No & Nc \\
\hline $\begin{array}{l}\text { TAIWAN OSTEOPOROSIS } \\
\text { PRACTICE GUIDELINES } \\
\text { BUREAU OF HEALTH } \\
\text { PROMOTION TAIWAN }\end{array}$ & Asia & 2011 & $\begin{array}{c}\text { General and } \\
\text { older population }\end{array}$ & Suggests & No & Yes & Supplementation & No & Nc \\
\hline $\begin{array}{l}\text { DUTCH DIETARY } \\
\text { GUIDELINES } 2015 \text { / } \\
\text { EVALUATION OF DIETARY } \\
\text { REFERENCE VALUES FOR } \\
\text { VTAMIN D } 5,6, \text { HEALTH } \\
\text { COUNCIL OF THE } \\
\text { NETHERLANDS }\end{array}$ & Europe & 2015 & $\begin{array}{c}\text { General } \\
\text { population }\end{array}$ & Suggests & No & Yes & Supplementation & Yes & Nc \\
\hline 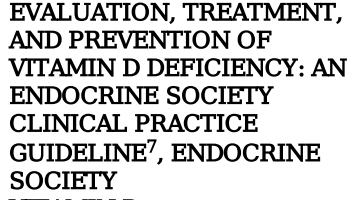 & $\begin{array}{c}\text { North } \\
\text { America }\end{array}$ & 2011 & $\begin{array}{c}\text { General } \\
\text { population }\end{array}$ & Suggests & $\begin{array}{l}\text { With risk } \\
\text { factors }\end{array}$ & No & Supplementation & No & Nc \\
\hline $\begin{array}{l}\text { VITAMIN D } \\
\text { SUPPLEMENTATION IN } \\
\text { ELDERLY OR } \\
\text { POSTMENOPAUSAL } \\
\text { WOMEN: A } 2013 \text { UPDATE OF } \\
\text { THE } 2008 \\
\text { RECOMMENDATIONS }^{8} \text {, } \\
\text { EUROPEAN SOCIETY FOR } \\
\text { CLINICAL AND ECONOMIC } \\
\text { ASPECTS OF } \\
\text { OSTEOPOROSIS AND } \\
\text { OSTEOARTHRTIS (ESCEO) }\end{array}$ & Europe & 2013 & $\begin{array}{c}\text { General } \\
\text { population }\end{array}$ & Suggests & $\begin{array}{l}\text { With risk } \\
\text { factors }\end{array}$ & Yes & Supplementation & No & Nc \\
\hline $\begin{array}{l}\text { DIETARY REFERENCE } \\
\text { INTAKES FOR CALCIUM } \\
\text { AND VITAMIN D } \\
\text { INSTITUTE OF MEDICINE }\end{array}$ & $\begin{array}{l}\text { North } \\
\text { America }\end{array}$ & 2011 & $\begin{array}{l}\text { General } \\
\text { population }\end{array}$ & $\begin{array}{c}\text { Does not recommend } \\
\qquad *\end{array}$ & No & Yes & $\begin{array}{l}\text { No method } \\
\text { favoured }\end{array}$ & No & Nc \\
\hline $\begin{array}{l}\text { IOF POSITION STATEMENT: } \\
\text { VTAMIN D } \\
\text { RECOMMENDATIONS FOR } \\
\text { OLDER ADULTS }{ }^{10} \text {, } \\
\text { INTERNATIONAL } \\
\text { OSTEOPOROSIS } \\
\text { FOUNDATION }\end{array}$ & International & 2013 & $\begin{array}{l}\text { Population older } \\
\text { than } 60\end{array}$ & Recommends & $\begin{array}{l}\text { With risk } \\
\text { factors }\end{array}$ & Yes & Supplementation & No & Ye: \\
\hline $\begin{array}{l}\text { OSTEOPOROSIS/FRACTURE } \\
\text { PREVENTION NATIONAL } \\
\text { GUIDELINE SUMMARY }{ }^{11} \\
\text { KAISER PERMANENTE }\end{array}$ & $\begin{array}{l}\text { North } \\
\text { America }\end{array}$ & 2014 & $\begin{array}{l}\text { Population older } \\
\text { than } 50 \text { and } \\
\text { women }\end{array}$ & Recommends & No & Yes & Supplementation & No & Nc \\
\hline $\begin{array}{l}\text { EVIDENCE-BASED } \\
\text { GUIDELINES FOR FALL } \\
\text { PREVENTION IN KOREA }{ }^{12} \text {, } \\
\text { KOREAN ASSOCIATION OF } \\
\text { INTERNAL MEDICINE }\end{array}$ & Asia & 2017 & $\begin{array}{c}\text { Older } \\
\text { population }\end{array}$ & Suggests & No & Yes & Supplementation & No & Nc \\
\hline $\begin{array}{l}\text { CALCIUM AND VTTAMIN D } \\
\text { SUPPLEMENTATIONS: } 2015 \\
\text { POSITION STATEMENT OF } \\
\text { THE KOREAN SOCIETY FOR } \\
\text { BONE AND MINERAL } \\
\text { RESEARCH }{ }^{13}, \text { KOREAN } \\
\text { BONE SOCIETY }\end{array}$ & Asia & 2015 & $\begin{array}{l}\text { Population older } \\
\text { than } 50\end{array}$ & Recommends & No & Yes & Supplementation & No & Ye: \\
\hline $\begin{array}{l}\text { FALLS: ASSESSMENT AND } \\
\text { PREVENTION OF FALLS IN } \\
\text { OLDER PEOPLE }^{14} \text {, } \\
\text { NATIONAL INSTITUE FOR } \\
\text { HEALTH AND CARE } \\
\text { EXCELLENCE (NICE) }\end{array}$ & Europe & 2013 & $\begin{array}{l}\text { Population older } \\
\text { than } 65\end{array}$ & $\begin{array}{c}\text { Does not recommend } \\
* * *\end{array}$ & No & Yes & $\begin{array}{l}\text { No method } \\
\text { favoured }\end{array}$ & No & Yes \\
\hline
\end{tabular}




\begin{tabular}{|c|c|c|c|c|c|c|c|c|c|}
\hline $\begin{array}{l}\text { PREVENTION AND } \\
\text { TREATMENT OF } \\
\text { OSTEOPOROSIS }{ }^{15} \text {, } \\
\text { NATIONAL OSTEOPOROSIS } \\
\text { FOUNDATION }\end{array}$ & $\begin{array}{c}\text { North } \\
\text { America }\end{array}$ & 2014 & $\begin{array}{c}\text { General } \\
\text { population }\end{array}$ & Suggests & $\begin{array}{l}\text { With risk } \\
\text { factors }\end{array}$ & No & Supplementation & No & $\mathrm{No}$ \\
\hline $\begin{array}{l}\text { THE NATIONAL } \\
\text { OSTEOPOROSIS } \\
\text { FOUNDATION'S POSITION } \\
\text { STATEMENT ON PEAK } \\
\text { BONE MASS } \\
\text { DEVELOPMENT AND } \\
\text { LIFESTYLE FACTORS: A } \\
\text { SYSTEMATIC REVIEW AND } \\
\text { IMPLEMENTATION } \\
\text { RECOMMENDATIONS }{ }^{16}, \\
\text { NATIONAL OSTEOPOROSIS } \\
\text { FOUNDATION }\end{array}$ & $\begin{array}{c}\text { North } \\
\text { America }\end{array}$ & 2016 & $\begin{array}{c}\text { General } \\
\text { population }\end{array}$ & Suggests & No & Yes & Supplementation & No & Nc \\
\hline $\begin{array}{l}\text { OSTEOPOROSIS CLINICAL } \\
\text { GUIDELINE FOR } \\
\text { PREVENTION AND } \\
\text { TREATMENT EXECUTIVE } \\
\text { SUMMARY }{ }^{17}, \text { NATIONAL } \\
\text { OSTEOPOROSIS GUIDELINE } \\
\text { GROUP }\end{array}$ & Europe & 2016 & $\begin{array}{c}\text { Older } \\
\text { population }\end{array}$ & Suggests & No & Yes & Supplementation & No & Yes \\
\hline $\begin{array}{l}\text { NORDIC NUTRITION } \\
\text { RECOMMENDATIONS 2012: } \\
\text { INTEGRATING NUTRITION } \\
\text { AND PHYSICAL ACTIVITY }{ }^{18} \text {, } \\
\text { NORDIC NUTRITION } \\
\text { RECOMMENDATIONS }\end{array}$ & Europe & 2012 & $\begin{array}{c}\text { General } \\
\text { population }\end{array}$ & Recommends & No & Yes & Supplementation & Yes & Nc \\
\hline $\begin{array}{l}\text { VTTAMIN D IN ADULT } \\
\text { HEALTH AND DISEASE: A } \\
\text { REVIEW AND GUIDELINE } \\
\text { STATEMENT FROM } \\
\text { OSTEOPOROSIS CANADA }{ }^{19} \text {, } \\
\text { OSTEOPOROSIS CANADA }\end{array}$ & $\begin{array}{c}\text { North } \\
\text { America }\end{array}$ & 2010 & $\begin{array}{c}\text { General } \\
\text { population }\end{array}$ & Recommends & $\begin{array}{l}\text { With risk } \\
\text { factors }\end{array}$ & Yes & Supplementation & Yes & Nc \\
\hline $\begin{array}{l}\text { PREVENTIVE ACTIVITIES IN } \\
\text { WOMEN }^{20} \text {, PROGRAM OF } \\
\text { PREVENTIVE ACTIVITIES IN } \\
\text { PRIMARY CARE (PAPPS), } \\
\text { SPANISH SOCIETY OF } \\
\text { FAMILY MEDICINE }\end{array}$ & Europe & 2014 & $\begin{array}{l}\text { Population older } \\
\text { than } 65\end{array}$ & Does not recommend & No & Yes & Supplementation & Yes & Nc \\
\hline $\begin{array}{l}\text { CLINICAL GUIDELINE FOR } \\
\text { THE PREVENTION AND } \\
\text { TREATMENT OF } \\
\text { OSTEOPOROSIS IN } \\
\text { POSTMENOPAUSAL } \\
\text { WOMEN AND OLDER MEN } \\
\text { AND TREATMENT OF } \\
\text { OSTEOPOROSIS IN } \\
\text { POSTMENOPAUSAL } \\
\text { WOMEN AND OLDER } \\
\text { MEN } 21, \text { ROYAL AUSTRALIAN } \\
\text { COLLEGE OF GENERAL } \\
\text { PRACTITIONERS }\end{array}$ & Oceania & 2010 & $\begin{array}{l}\text { Postmenopausal } \\
\text { women and } \\
\text { older men }\end{array}$ & Does not recommend & No & Yes & Sun exposure & Yes & Nc \\
\hline $\begin{array}{l}\text { SWISS FEDERAL } \\
\text { COMMISSION } \\
\text { RECOMMENDATIONS } \\
\text { REGARDING VITAMIN D } \\
\text { UPTAKE }{ }^{22}, \text { SWISS FEDERAL } \\
\text { COMMISSION }\end{array}$ & Europe & 2012 & $\begin{array}{c}\text { General } \\
\text { population }\end{array}$ & Recommends & $\begin{array}{l}\text { With risk } \\
\text { factors }\end{array}$ & No & Supplementation & No & Ye: \\
\hline $\begin{array}{l}\text { CLINICAL PRACTICE } \\
\text { GUIDELINES FOR VITAMIN } \\
\text { D IN THE UNITED ARAB } \\
\text { EMIRATES }^{23} \text {, UNITED ARAB } \\
\text { EMIRATES }\end{array}$ & Asia & 2016 & $\begin{array}{c}\text { General } \\
\text { population }\end{array}$ & Recommends & $\begin{array}{l}\text { With risk } \\
\text { factors }\end{array}$ & No & Supplementation & No & Nc \\
\hline $\begin{array}{l}\text { VTTAMIN D AND CALCIUM } \\
\text { SUPPLEMENTATION TO } \\
\text { PREVENT FRACTURES IN } \\
\text { ADULTS: U.S. PREVENTIVE } \\
\text { SERVICES TASK FORCE } \\
\text { RECOMMENDATION } \\
\text { STATEMENT }^{24}, \text { UNITED } \\
\text { STATES PREVENTIVE } \\
\text { SERVICES TASK FORCE }\end{array}$ & $\begin{array}{c}\text { North } \\
\text { America }\end{array}$ & 2013 & $\begin{array}{l}\text { Population older } \\
\text { than } 65\end{array}$ & Does not recommend & No & Yes & Supplementation & No & Ye؛ \\
\hline $\begin{array}{l}\text { GUIDELINE: VITAMIN D } \\
\text { SUPPLEMENTATION IN } \\
\text { PREGNANT WOMEN }{ }^{25} \text {, } \\
\text { VITAMIN D } \\
\text { SUPPLEMENTATION IN } \\
\text { PREGNANT WOMEN, } \\
\text { WORLD HEALTH } \\
\text { ORGANISATION }\end{array}$ & International & 2012 & $\begin{array}{l}\text { Pregnant } \\
\text { women }\end{array}$ & Does not recommend & No & No & $\begin{array}{l}\text { No method } \\
\text { favoured }\end{array}$ & No & Nc \\
\hline
\end{tabular}

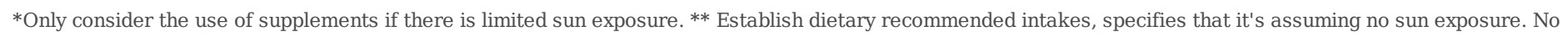

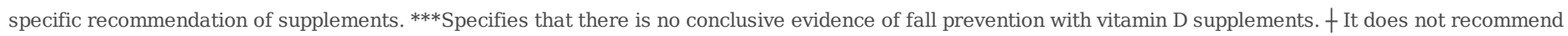
supplements for preventing fractures but does it to prevent falls in older adults with high risk. 
Table 2: Vitamin D supplementation per population.

NAME OF ORGANIZATION

AMERICAN GERIATRICS SOCIETY

AUSTRALIA AND NEW ZEALAND BONE AND MINERAL SOCIETY \& OSTEOPOROSIS AUSTRALIA

BRITISH COLUMBIA MEDICAL ASSOCIATION

BUREAU OF HEALTH PROMOTION TAIWAN

DUTCH HEALTH COUNCIL

ENDOCRINE SOCIETY

EUROPEAN SOCIETY FOR CLINICAL AND ECONOMIC ASPECTS OF OSTEOPOROSIS

AND OSTEOARTHRITIS

INSTITUTE OF MEDICINE

INTERNATIONAL OSTEOPOROSIS FOUNDATION

KAISER PERMANENTE

KOREAN ASSOCIATION OF INTERNAL MEDICINE

KOREAN BONE SOCIETY

NATIONAL INSITITUTE FOR HEALTH ANC CARE EXCELLENCE

NATIONAL OSTEOPOROSIS FOUNDATION OSTEOPOROSIS PREVENTION

GUIDELINE

NATIONAL OSTEOPOROSIS FOUNDATION PEAK BONE MASS RECOMMENDATIONS

NATIONAL OSTEOPOROSIS GUIDELINE GROUP

NORDIC NUTRITION RECOMMENDATIONS

OSTEOPOROSIS CANADA

SPANISH FAMILY MEDICINE SOCIETY

ROYAL AUSTRALIAN COLLEGE OF GENERAL PRACTITIONERS

SWISS FEDERAL COMMISSION

UNITED ARAB EMIRATES

UNITED STATES PREVENTIVE SERVICES TASK FORCE

WORLD HEALTH ORGANIZATION: VITAMIN D SUPPLEMENTATION IN PREGNANT

WOMEN

\section{TARGET POPULATION PAEDIATRIC ADULT ELDER WOMEN}

\begin{tabular}{|c|c|c|c|c|}
\hline Population older than 65 & & & [ & \\
\hline General population & [] & प] & प & प \\
\hline General population & प] & $\square$ & प & \\
\hline General and older population & & प & [ & \\
\hline General population & ] & प & प & \\
\hline General population & ] & प] & [ & ] \\
\hline General population & [ & प & प & [ \\
\hline General population & प] & $\square$ & [ & \\
\hline Population older than 60 & & & प & \\
\hline $\begin{array}{l}\text { Population older than } 50 \text { and } \\
\text { women }\end{array}$ & & & [ & [ \\
\hline
\end{tabular}

Population older than 65

Population older than 50

Population older than 65

General population

General population

Older population

General population

General population

Population older than 65

Postmenopausal women and older men

General population

General population

Population older than 65

Pregnant women

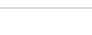

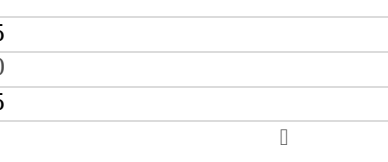

\begin{tabular}{llll} 
& 0 & 0 & \\
& & 0 & \\
& 0 & 0 & $\square$ \\
65 & $\square$ & $\square$ & \\
and & & $\square$ & $\square$ \\
\hline
\end{tabular}

$\begin{array}{ll}\square & \square \\ \square & \square\end{array}$

]

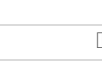

Table 3: Conflicts of interest reporting in guidelines. 
$\begin{array}{llll}\text { COI } & \text { COI } & \text { COI } & \text { COI }\end{array}$ PROCESS REPORTING REPORTING REPORTING REPORTING AFFILIATION FINANCIAL INTELLECTUAL

THE NATIONAL OSTEOPOROSIS FOUNDATION'S POSITION STATEMENT ON PEAK BONE MASS DEVELOPMENT AND LIFESTYLE FACTORS: A SYSTEMATIC REVIEW AND IMPLEMENTATION RECOMMENDATIONS, NATIONAL OSTEOPOROSIS FOUNDATION

VITAMIN D FOR PREVENTION OF FALLS AND THEIR CONSEOUENCES IN OLDER

ADULTS, AMERICAN GERIATRICS SOCIETY OSTEOPOROSIS CLINICAL GUIDELINE FOR PREVENTION AND TREATMENT EXECUTIVE SUMMARY, NATIONAL OSTEOPOROSIS GUIDELINE GROUP

EVALUATION, TREATMENT, AND

PREVENTION OF VITAMIN D DEFICIENCY:

AN ENDOCRINE SOCIETY CLINICAL

PRACTICE GUIDELINE, ENDOCRINE

SOCIETY

IOF POSITION STATEMENT: VITAMIN D

RECOMMENDATIONS FOR OLDER ADULTS, INTERNATIONAL OSTEOPOROSIS

FOUNDATION

VTTAMIN D AND CALCIUM

SUPPLEMENTATION TO PREVENT

FRACTURES IN ADULTS: U.S. PREVENTIVE SERVICES TASK FORCE

RECOMMENDATION STATEMENT, UNITED STATES PREVENTIVE SERVICES TASK

FORCE

PREVENTIVE ACTIVITIES IN WOMEN,

PROGRAM OF PREVENTIVE ACTIVTTIES IN PRIMARY CARE (PAPPS), SPANISH SOCIETY OF FAMILY MEDICINE

NORDIC NUTRITION RECOMMENDATIONS 2012: INTEGRATING NUTRITION AND PHYSICAL ACTIVITY, NORDIC NUTRITION RECOMMENDATIONS

DUTCH DIETARY GUIDELINES 2015

EVALUATION OF DIETARY REFERENCE

VALUES FOR VITAMIN D, HEALTH COUNCIL OF THE NETHERLANDS

DIETARY REFERENCE INTAKES FOR

CALCIUM AND VITAMIN D, INSTITUTE OF

MEDICINE

SWISS FEDERAL COMMISSION

RECOMMENDATIONS REGARDING VITAMIN

D UPTAKE, SWISS FEDERAL COMMISSION

VTTAMIN D SUPPLEMENTATION IN

ELDERLY OR POSTMENOPAUSAL WOMEN:

A 2013 UPDATE OF THE 2008

RECOMMENDATIONS, EUROPEAN SOCIETY

FOR CLINICAL AND ECONOMIC ASPECTS

OF OSTEOPOROSIS AND OSTEOARTHRITIS.

BUILDING HEALTHY BONES THROUGHOUT

LIFE AN EVIDENCE-INFORMED STRATEGY

TO PREVENT OSTEOPOROSIS IN

AUSTRALIA, AUSTRALIA AND NEW

ZEALAND BONE AND MINERAL SOCIETY \&

OSTEOPOROSIS AUSTRALIA

CALCIUM AND VITAMIN D

SUPPLEMENTATIONS: 2015 POSITION

STATEMENT OF THE KOREAN SOCIETY

FOR BONE AND MINERAL RESEARCH,

KOREAN BONE SOCIETY

OSTEOPOROSIS: DIAGNOSIS, TREATMENT

AND FRACTURE PREVENTION, BRITISH

COLUMBIA MEDICAL ASSOCIATION

CLINICAL GUIDELINE FOR THE

PREVENTION AND TREATMENT OF

OSTEOPOROSIS IN POSTMENOPAUSAL

WOMEN AND OLDER MEN AND TREATMENT

OF OSTEOPOROSIS IN POSTMENOPAUSAI

WOMEN AND OLDER MEN, ROYAL

AUSTRALIAN COLLEGE OF GENERAL

PRACTITIONERS

TAIWAN OSTEOPOROSIS PRACTICE

GUIDELINES, BUREAU OF HEALTH

PROMOTION TAIWAN

FALLS: ASSESSMENT AND PREVENTION OF

FALLS IN OLDER PEOPLE, NATIONAL

INSTITUTE FOR HEALTH AND CARE

EXCELLENCE (NICE)

OSTEOPOROSIS/FRACTURE PREVENTION

NATIONAL GUIDELINE SUMMARY, KAISER

PERMANENTE

GUIDELINE: VITAMIN D

Clea

No

Yes

No

.

Cle

Not Reported Not

Not Reported

Reported

Reported
FINANCIAL

ADVOCATORY

OVERALL

\begin{tabular}{|c|c|c|c|c|c|c|}
\hline Clear & Yes & Yes & No & Unclear & & Detected \\
\hline Clear & No & Yes & No & Yes & Yes & Detected \\
\hline Clear & Yes & Yes & Yes & Yes & & Detected \\
\hline Clear & No & Yes & No & Unclear & Yes & Detected \\
\hline Clear & Yes & Yes & Yes & No & No & Undetect \\
\hline
\end{tabular}

$\begin{array}{lllll}\text { No } & \text { Yes } & \text { No } & \text { Unclear } & \text { No }\end{array}$

Not Reported

Not Reported

Not Reported

\begin{tabular}{|lcccccc} 
Unclear & Yes & No & No & No & No & Undetected \\
\hline Clear & No & Yes & No & No & Unclear & Detected \\
Clear & Yes & Yes & No & Unclear & Yes & Detected
\end{tabular}

$\begin{array}{llllll}\text { Clear } & \text { No } & \text { Yes } & \text { No } & \text { Yes } & \text { Unclear }\end{array}$

$\begin{array}{llllll}\text { Clear No } & \text { Yes } & \text { No } & \text { Unclear } & \text { Unclear }\end{array}$

$\begin{array}{lllllll}\text { Clear } & \text { No } & \text { Yes } & \text { No } & \text { Unclear } & \text { Unclear } & \text { Undetected } \\ \text { Clear } & \text { Yes } & \text { Yes } & \text { Yes } & \text { No } & \text { No } & \text { Undetected }\end{array}$

$\begin{array}{llllll}\text { Clear } & \text { No } & \text { Yes } & \text { Yes } & \text { No } & \text { Undetected } \\ \text { Clear } & \text { Yes } & \text { Yes } & \text { Yes } & \text { No } & \text { No }\end{array}$

$\begin{array}{lllllll}\begin{array}{l}\text { Not } \\ \text { Reported }\end{array} & \text { Not Reported } & \begin{array}{l}\text { Not } \\ \text { Reported }\end{array} & \text { Not Reported } & \text { Not Reported } & \text { Not Reported } & \text { Not Reported } \\ \text { Clear } & \text { No } & \text { Yes } & \text { Yes } & \text { No } & \text { Unclear } & \text { Undetected }\end{array}$


SUPPLEMENTATION IN PREGNANT WOMEN, VITAMIN D SUPPLEMENTATION IN

PREGNANT WOMEN

CLINICIAN'S GUIDE TO PREVENTION AND

TREATMENT OF OSTEOPOROSIS

NATIONAL OSTEOPOROSIS FOUNDATION

EVIDENCE-BASED GUIDELINES FOR FALL

PREVENTION IN KOREA, KOREAN

ASSOCIATION OF INTERNAL MEDICINE

CLINICAL PRACTICE GUIDELINES FOR

VITAMIN D IN THE UNITED ARAB

EMIRATES, UNITED ARAB EMIRATES

VITAMIN D IN ADULT HEALTH AND

DISEASE: A REVIEW AND GUIDELINE

STATEMENT FROM OSTEOPOROSIS

CANADA, OSTEOPOROSIS CANADA

\begin{tabular}{lllllll}
\hline Clear & No & Yes & No & Yes & Unclear & Detected \\
\hline Unclear & Yes & No & No & No & Unclear & Detected \\
$\begin{array}{l}\text { Not } \\
\text { Reported }\end{array}$ & Not Reported & $\begin{array}{l}\text { Not } \\
\text { Reported }\end{array}$ & Not Reported & Not Reported & Not Reported & Not Reported \\
Clear & Yes & Yes & No & Yes & Yes & Detected
\end{tabular}

\section{Figures}

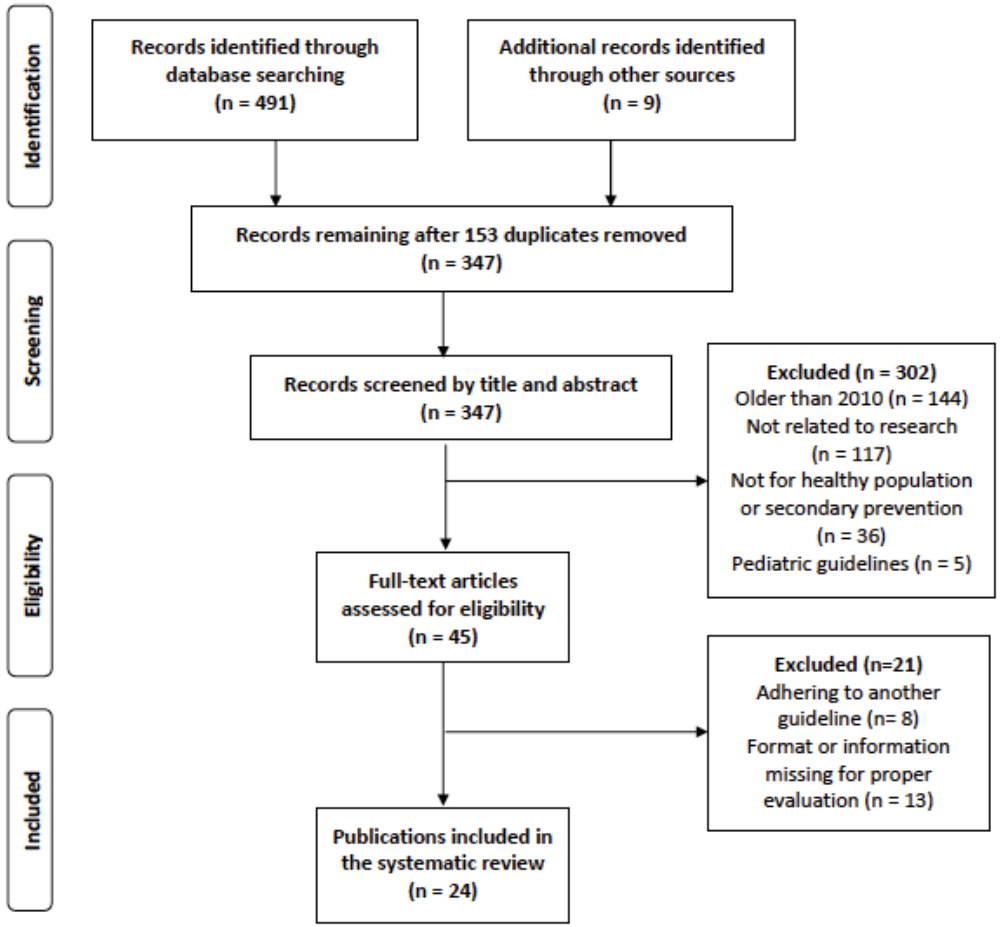

Figure 1

PRISMA Flow chart 

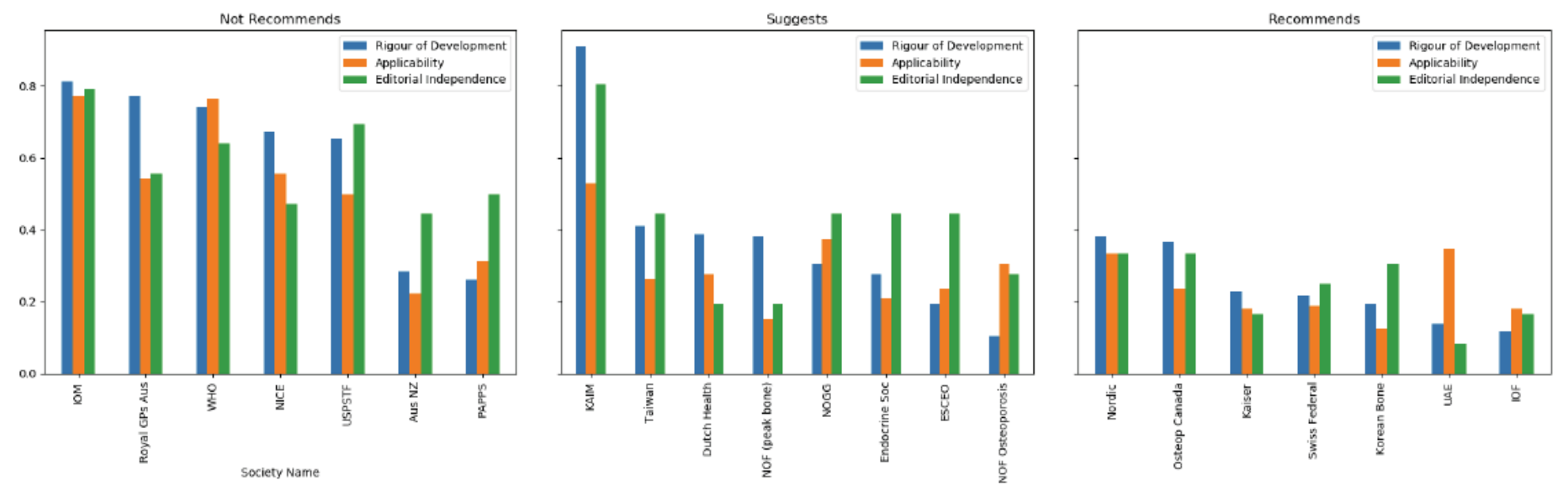

*Acronym / abbreviation correspondence with society and/or guidelines:

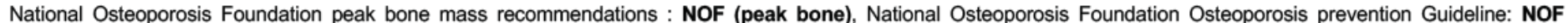

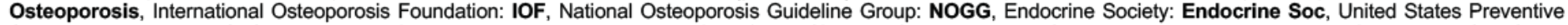

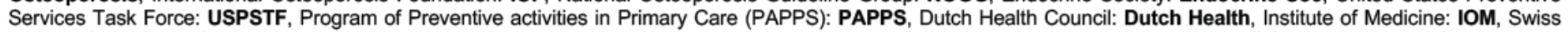

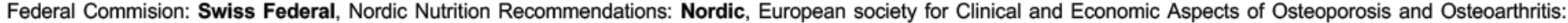

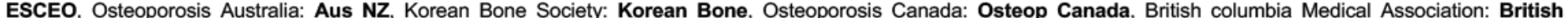

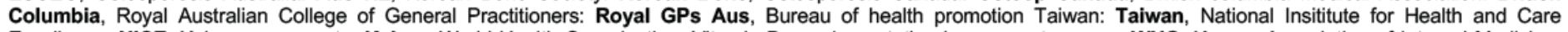

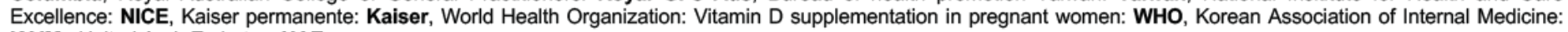
KAIM, United Arab Emirates: UAE.

\section{Figure 2}

AGREE II domains in guidelines score by type of recommendation given

\section{Supplementary Files}

This is a list of supplementary files associated with this preprint. Click to download.

- supplement1.docx

- supplement2.xlsx

- supplement3.docx

- supplement4.docx

- supplement5.docx 